\title{
Quality of life in obese women with symptoms of urinary incontinence
}

\author{
Qualidade de vida em mulheres obesas com sintomas de \\ incontinência urinária
}

\section{Calidad de vida en mujeres obesas con síntomas de incontinencia urinaria}

\author{
Eli Maria Pazzianotto-Forti ${ }^{[a]}$, Patrícia Brigatto ${ }^{[a]}$, Letícia Baltieri ${ }^{[b]}$,

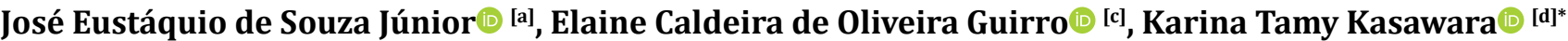

[a] Universidade Metodista de Piracicaba (UNIMEP), Piracicaba, SP, Brazil

[b] Universidade Estadual de Campinas (UNICAMP), Campinas, SP, Brazil

[c] Universidade de São Paulo (USP), Ribeirão Preto, SP, Brazil

[d] Universidade de Toronto (U of T), Toronto, ON, Canada

\section{Abstract}

Introduction: Obesity is a contributing factor to the development of urinary incontinence (UI). Objective: The objective of this study was to evaluate the prevalence of UI symptoms in women with morbid obesity and their impacts on quality of life (QOL), correlating the influence of age and body mass index (BMI) with the presence of UI. Method: Sixty-five women undergoing preoperative bariatric surgery, aged 35.8 \pm 9.97 years, with an average BMI of $45.04 \pm 6.79 \mathrm{~kg} / \mathrm{m}^{2}$ were asked about the presence of UI symptoms; when they answered positively, the King's Health Questionnaire (validated into Portuguese) was applied. The questionnaire was self-administered

\footnotetext{
* EMPF: PhD, e-mail: empforti@unimep.br PB: MS, e-mail: patricia.brigatto@gmail.com LB: PhD, e-mail: lbaltieri@yahoo.com.br JESJ: MS, e-mail: jejr.fisio@gmail.com ECOG: PhD, e-mail: ecguirro@fmrp.usp.br KTK: PhD, e-mail: karina.tamy@gmail.com
} 
and all answers were assigned numerical scores. These scores were distributed according to quartiles and correlated with age and BMI. The level of hypothesis rejection was $5 \%$, and analyses were performed using BioEstat software version 5.3. Results: Among 65 interviewees, 19 (29.23\%) had symptoms of UI and went on to answer the questionnaire. The highest-scoring areas were "incontinence impact" (36.8) and "general health perception" (32.9). There was no significant correlation between questionnaire scores and BMI. In the association with age, the "incontinence impact" domain showed a significant, positive and moderate correlation $(r=0.52 ; p=0.02)$. Conclusion: The prevalence of UI symptoms in the sample had a slight negative effect on QOL; however, UI associated with older ages significantly affected the QOL of the studied volunteers.

Keywords: Urinary Incontinence. Obesity. Quality of Life.

\section{Resumo}

Introdução: A obesidade é considerada um fator contribuinte para o desenvolvimento da incontinência urinária (IU). Objetivo: O objetivo deste estudo foi avaliar a prevalência dos sintomas da IU em mulheres obesas mórbidas, seu impacto sobre a qualidade de vida (QV) e correlacionar a influência da idade e do índice de massa corporal (IMC) sobre a presença de IU. Método: Foram avaliadas, 65 mulheres, em

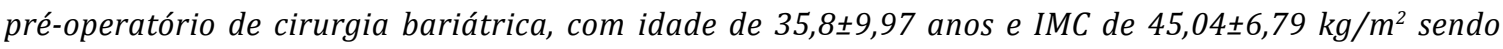
questionadas sobre sintomas de IU e, se confirmados, responderam ao King's Health Questionnaire, validado para o português. $O$ questionário foi auto administrado e foram atribuídos valores numéricos às respostas, esses escores foram avaliados em quartis e correlacionados com a idade e o IMC. O nível de rejeição da hipótese foi $5 \%$ e as análises foram realizadas com o software BioEstat, versão 5.3. Resultados: Das 65 mulheres que foram entrevistadas, dezenove delas (29,23\%) apresentaram os sintomas da IU e responderam ao questionário. Os domínios que apresentaram maior pontuação foram "impacto da IU" $(36,8)$ e "percepção geral da saúde" $(32,9)$. Não foi encontrada correlação significativa entre os escores do questionário e o IMC. Já na associação com a idade, o domínio "impacto da IU" apresentou correlação positiva, significativa e moderada ( $r=0,52 ; p=0,02)$. Conclusão: Diante dos achados, com a prevalência de sintomas de IU na amostra estudada, pode-se inferir que a IU compromete pouco a QV, entretanto o aumento da idade quando associada à IU pode afetar significativamente a QV de mulheres obesas classe II e III.

Palavras-chave: Incontinência Urinária. Obesidade. Qualidade de Vida.

\section{Resumen}

Introducción: La obesidad se considera un factor contribuyente para el desarrollo de la incontinencia urinaria (IU). Objetivo: El objetivo de este estudio fue evaluar la prevalencia de los síntomas de IU en las mujeres obesas morbidas, el impacto en la calidad de vida (CV), y la influencia de la edad y el índice de masa corporal (IMC) sobre la presencia de IU. Método: Fueron evaluados 65 mujeres, en preoperatorio de cirugía bariátrica, con edad de 35,8 \pm 9,97 años e IMC de 45,04 $\pm 6,79 \mathrm{~kg} / \mathrm{m}^{2}$ siendo cuestionadas sobre síntomas de IU y, si confirmados, respondieron al King's Health Questionnaire, validado para el portugués. El cuestionario fue auto administrado y se asignaron valores numéricos a las respuestas, los escores fueron evaluados en cuartiles y correlacionados con la edad y el IMC. El nivel de rechazo del análisis fue del 5\% y los análisis se realizaron con el software BioEstat, versión 5.3. Resultados: De las 65 mujeres que fueron entrevistadas, diecinueve de ellas (29,23\%) presentaron los síntomas de la IU y respondieron al cuestionario. Los dominios que presentaron mayor puntuación fueron "impacto de la IU" $(36,8)$ y "percepción general de la salud" $(32,9)$. No se encontró correlación significativa entre los puntajes del cuestionario y el IMC. En la asociación con la edad, el dominio "impacto de la IU" presentó correlación positiva, significativa y moderada ( $r=0,52 ; p=0,02)$. Conclusión: Ante los hallazgos, con la prevalencia de síntomas de IU en la populacion 
estudiada, se puede inferir que la IU compromete poco la QV, sin embargo el aumento de la edad cuando está asociada a la IU puede afectar significativamente a la CV de mujeres obesas clase II y III.

Palabras clave: Incontinencia Urinaria. Obesidad. Calidad de Vida.

\section{Introduction}

The International Continence Society (ICS) [1] describes urinary incontinence (UI) as any complaint of involuntary leakage of urine, which compromises social relationships and hygiene. Considering all the risk factors associated with increased UI prevalence, such as menopause, constipation, arterial hypertension, diabetes, smoking, family history of UI, and parity, it is clear that obesity requires special healthcare attention [2]. Furthermore, UI is an important predisposing factor for the development of stress UI, due to the increase in abdominal adiposity [3]. Obesity and increased abdominal pressure exert greater pressure in the bladder and urethra, impairing blood flow and innervation of the bladder, altering the urinary tract's mechanism, aggravating instability of the detrusor muscle, resulting in stress UI and overactive bladder [4].

It is known that an increase of five units in body mass index (BMI) is associated with an increase of about 20 to $70 \%$ in the risk of developing UI [58]. It is estimated that 46 to $67 \%$ of women with obesity and morbid obesity have UI. The latter acts as a determinant of health-related problems involving social, sexual, psychic and economic relationships, triggering feelings of low self-esteem, restricting social life, and difficulting individuals' foray into the job market $[8,9]$, all of which reduce women's quality of life (QOL) $[7,10]$. UI is not a change intrinsic to the aging process, although its incidence does increase linearly with age [11], promoting negative impacts, especially those associated with BMI increase and hormonal changes that occur in menopause [4]. On the other hand, UI affects more than $10 \%$ of obese adolescents, and in this population the frequency and volume of urine loss are directly related to selfreported symptom impact [12].

Brown et al. [10] suggested that women with BMI higher than $30 \mathrm{~kg} / \mathrm{m}^{2}$ have roughly a $40 \%$ higher risk of developing UI in comparison to women with normal BMI $\left(<29.9 \mathrm{~kg} / \mathrm{m}^{2}\right)$, showing a positive correlation between UI and obesity.
There is strong evidence that bariatric surgery is effective in treating the most common types of UI (stress UI), because it promotes body mass reduction $[13,14]$, regardless of the reproductive history of the patients, the existence of comorbidities such as hypertension and diabetes or smoking [14].

The beneficial results of bariatric surgery for improving UI in morbidly obese women are worthy of notice. Castro et al. [11] found a UI prevalence of $70.8 \%$ in women undergoing preoperative preparation for bariatric surgery, and concluded that loss of weight by means of bariatric surgery had a positive effect on patients' pelvic floor function and QOL.

In cases of UI associated with morbid obesity, physical therapy plays an important role in these patients' life both before and after bariatric surgery [10]. Considering the effects of such a condition over QOL, physical therapy of the pelvic floor muscle, recommended by the American College of Physicians (ACP) as a first-line treatment for women with stress UI [15], can reduce UI-related symptoms, improving social, physical, psychological and emotional aspects, and thus QOL itself $[10,16]$.

Thus, this study's hypothesis was that women with morbid obesity waiting for bariatric surgery would present a higher UI prevalence due to their high BMI values. Moreover, since UI symptoms may negatively impact women's QOL, a positive correlation of age and BMI with UI would also be found.

Hence, the objective of this study was to evaluate the prevalence of UI symptoms reported by women with morbid obesity, as well as its impact on women's QOL, correlating UI with age and BMI.

\section{Methods}

Participants

This was an observational study about the impact of UI on obese women's quality of life. This study was approved by Methodist University of Piracicaba Research Ethics Board (process number 54/13). 
All participants signed an informed consent form, in observance of Conselho Nacional de Saúde (CNS) resolution no. 466/2012.

Inclusion criteria were: $\mathrm{BMI} \geq 40 \mathrm{~kg} / \mathrm{m}^{2}$, older than 18 years, and having signed the consent form. Exclusion criteria were: previous hysterectomy, previous vaginal delivery, UI during pregnancy or postpartum period, smoking, and diabetes.

In total, 65 women aged between 21 and 58 years (35.8 \pm 9.97 years) participated in this study. Participants had a mean BMI between 36.27 and $69.77 \mathrm{~kg} / \mathrm{m}^{2}\left(45.04 \pm 6.79 \mathrm{~kg} / \mathrm{m}^{2}\right)$. Women were recruited during the postoperative period of bariatric surgery, in a specialized clinic for the treatment of obesity. Data collection was performed during three months, and participants were included according to the order in which they formally accepted to take part in the study.

\section{Procedures}

Clinical history was used to confirm the presence of UI [17]. Following the criteria described by Simeonova et al. [18], participants were asked about the presence of UI symptoms, such as sudden desire to urinate or urine leakage when coughing, sneezing or performing any physical activity. Patients were evaluated using anthropometric measurements, according to their body mass and height as calculated by the BMI formula: person's weight in kilograms divided by their height in meters squared.

Participant's who confirmed having UI symptoms answered the Portuguese version of the King's Health Questionnaire (KHQ). The questionnaire was self-administered [19], with no researcher interference over respondents' answers. The KHQ was translated and adapted to the Portuguese language; the adapted version was found to be highly reliable and valid for both research purposes and UI clinical practice $[4,19]$. As a questionnaire specifically geared towards the evaluation of women with UI, the KHQ is able to provide consistent results regarding the presence of complaints and symptoms of UI, as well as the condition's QOL impact on the various dimensions of individuality, thus allowing for a consistent general assessment of the dysfunction [20].

The KHQ consists of 30 questions divided into nine domains: general health perception, incontinence impact, role limitations, physical limitations, social limitations, personal relationships, emotions, sleep and energy, and severity measures. The questionnaire also addresses a variety of symptoms: urinary frequency, nocturia, urgency, bladder hyperreflexia, stress urinary incontinence, nocturnal enuresis, incontinence during sexual intercourse, urinary infections, and bladder pain. All answers are measured by a numeric score, summed, and evaluated according to domain. These values are calculated using a mathematical formula for obtaining the score of each domain, which varies from 0 to 100 . The higher the score, the worse the related QOL [4].

The answers are based on an increasing numerical scale, proportional to the intensity of the complaint $(0=$ Not at all; $1=$ A little; $2=$ Moderately; $3=$ All the time), with the exception of general health perception, which is divided into five alternatives: very good, good, fair, poor and very poor. For this study, eight of the questionnaire's nine domains were analyzed (general health perception, incontinence impact, role limitations, physical limitations, social limitations, personal relationships, emotions, sleep and energy). These address important and influential factors in the QOL of women with UI. The 65 participants included in this study were divided into two groups, according to the presence or absence of UI symptoms.

Statistical analysis

For comparing age and BMI among groups, normality of data distribution was measured by the Shapiro-Wilk test, and then the nonparametric Mann-Whitney test was applied. The data was presented in median, $1^{\text {st }}$ and $3^{\text {rd }}$ quartile of each domain score. For KHQ domain analysis, the nonparametric Spearman test was performed, so as to evaluate the correlation between questionnaire scores, age, and BMI. The null hypothesis rejection level was set at $5 \%$. All analyzes were performed using BioEstat software version 5.3.

\section{Results}

Among the 65 obese women interviewed, 19 reported UI symptoms (29.23\%), while 46 did not report any UI symptoms (70.77\%). Descriptive data are presented in Table 1. 
Table 1 - Participants' data regarding age and body mass index, divided in two groups according to the presence of urinary incontinence symptoms. Values are expressed as mean and standard deviation

\begin{tabular}{lcc}
\hline & \multicolumn{2}{c}{ Participants $(\mathrm{n}=\mathbf{6 5})$} \\
\cline { 2 - 3 } & $\begin{array}{l}\text { Women with urinary incontinence symptoms } \\
(\mathbf{n}=\mathbf{1 9})\end{array}$ & $\begin{array}{c}\text { Women without urinary incontinence symptoms } \\
(\mathbf{n}=46)\end{array}$ \\
\hline Age (years) & $41.84 \pm 9.99$ & $33.30 \pm 8.92^{*}$ \\
Body mass index $\left(\mathrm{kg} / \mathrm{m}^{2}\right)$ & $46.73 \pm 8.33$ & $44.34 \pm 6.00$ \\
\hline
\end{tabular}

Note: ${ }^{*}$ : value statistically significant between groups ( $p$-value $=0.0023$ ).

In respect to UI type, 19 participants reported urine leakage when coughing, sneezing or performing any kind of physical activity. According to criteria described by Simeonova et al. [18], this was considered stress urinary incontinence.

There was a significant age difference when comparing groups with and without UI symptoms ( $p=0.0023 ; r=0.52)$, as women with UI symptoms were older (Figure 1). However, there was no significant BMI difference between groups.

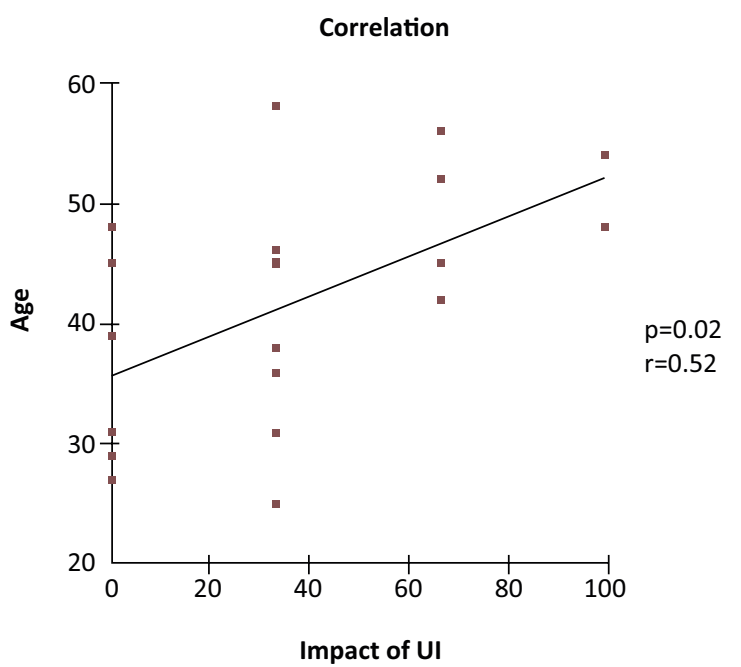

Figure 1 - Correlation between age and scores obtained in the "incontinence impact" domain.

All participants were considered obese. BMI ranged from $36.27 \mathrm{~kg} / \mathrm{m}^{2}$ to $69.27 \mathrm{~kg} / \mathrm{m}^{2}$ (obesity class II e III), with a significant difference between groups.

The KHQ scores of each domain as self-reported by participants with UI symptoms and their impact on QOL are shown as medians, 1 st $\left(Q_{1 / 4}\right)$ and $3 r d\left(Q_{3 / 4}\right)$ quartiles in Figure 2.

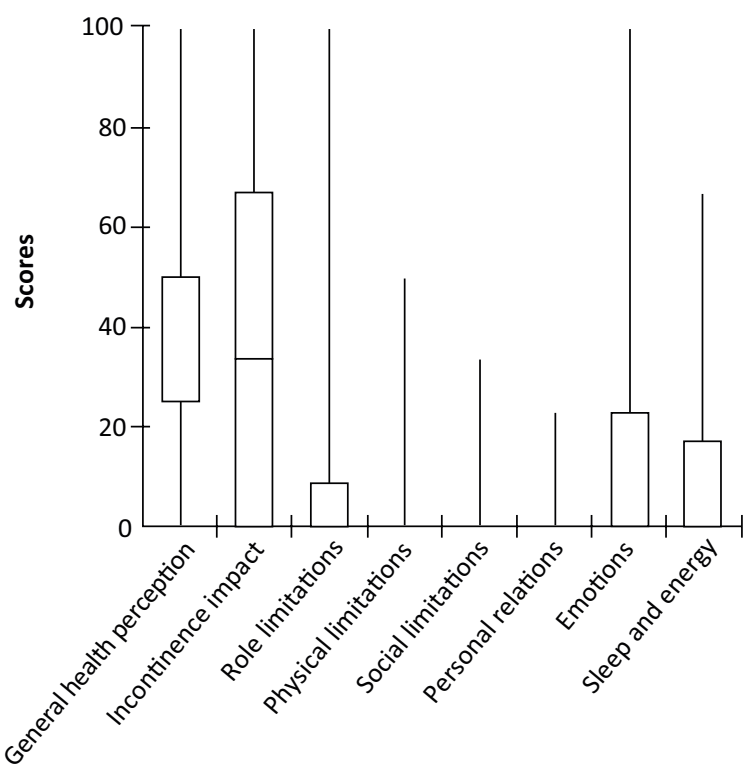

Figure 2 - Scores obtained by participants in each domain of the questionnaire. Values are presented as median, $1^{\text {st }}$ and $3^{\text {rd }}$ quartile.

Among participants with UI symptoms, only $47.3 \%$ $(\mathrm{n}=9)$ classified their general health perception as "good," with a median score of $25\left(Q_{1 / 4}=25 ; Q_{3 / 4}=50\right)$ for this domain. Evaluating the impact of UI symptoms over their lives, $36.9 \%(n=7)$ participants reported that UI had "a little" impact. The median score for this domain was $33.33\left(Q_{1 / 4}=0 ; Q_{3 / 4}=66.67\right)$.

When questioned about role limitations as a consequence of UI, 79\% ( $n=15)$ reported that UI did not affect any of their activities at home or outside the home, with a median score of zero $\left(Q_{1 / 4}=0 ; Q_{3 / 4}=8.33\right)$.

No physical limitation was reported by $84.2 \%$ of the respondents $(n=16)$. UI did not affect their ability to walk, run, play sports or go to the gym, or their ability to travel. The median score in this domain was zero $\left(Q_{1 / 4}=0 ; Q_{3 / 4}=0\right)$, indicating its negligible 
influence over women's QOL. Furthermore, "social limitations" were reported to have no effect on participants' relationships with family and friends, as $89.5 \%(\mathrm{n}=17)$ answered "not at all," resulting in a median score of zero for this domain $\left(Q_{1 / 4}=0, Q_{3 / 4}=0\right)$.

Both the "personal relationships" and "emotions" domains presented a median score of zero $\left(Q_{1 / 4}=0\right.$; $\mathrm{Q}_{3 / 4}=0$ and $\mathrm{Q}_{1 / 4}=0, \mathrm{Q}_{3 / 4}=22.22$, respectively). In total, $89.5 \%$ participants $(n=17)$ reported that UI did not affect their relationships or sex life, whereas $10.5 \%$ $(\mathrm{n}=2)$ reported this domain as "not applicable" to their sexual life. Moreover, $73.7 \%$ participants $(\mathrm{n}=14)$ reported not having any issues with their self-esteem, and $68.4 \%(n=13)$ stated that they did not feel depressed, anxious or nervous.

In the eighth KHQ domain, "sleep and energy," $84.2 \%$ participants $(n=16)$ reported that bladder problems had no effect "at all" over their sleep, while $63.2 \%(n=12)$ reported that bladder problems did not make them feel "at all" worn out and tired. This domain presented a median score of zero $\left(Q_{1 / 4}=0\right.$; $\mathrm{Q}_{3 / 4}=16.67$ ).

Concerning the correlation between BMI and each questionnaire domain, BMI had no association with the following: "general health perception" $(r=-0.21$; $\mathrm{p}=0.40)$; "incontinence impact" $(\mathrm{r}=0.37 ; \mathrm{p}=0.12)$; "role limitations" ( $\mathrm{r}=0.29 ; \mathrm{p}=0.22)$; "physical limitations" $(r=0.01 ; p=0.97)$; "social limitations" $(\mathrm{r}=0.15 ; \mathrm{p}=0.55)$; "emotions" $(\mathrm{r}=0.30 ; \mathrm{p}=0.21)$; "sleep and energy" ( $r=0.26 ; p=0.28)$.

It was not possible to measure the correlation between "personal relationships" with BMI and age, because all participants reported a score of zero for this domain.

Age and "incontinence impact" had a significant, positive and moderate correlation $(\mathrm{r}=0.52 ; \mathrm{p}=0.02)$ (Figure 2). However, age was not significantly correlated to the other domains: "general health perception" ( $r=0.14 ; p=0.58)$; "role limitations" $(\mathrm{r}=0.45 ; \mathrm{p}=0.052)$; "physical limitations" $(\mathrm{r}=0.10$; $\mathrm{p}=0.68)$; "social limitations" $(\mathrm{r}=0.26 ; \mathrm{p}=0.28)$; "emotions" ( $r=0.25 ; p=0,30)$; "sleep and energy" $(\mathrm{r}=0 ; \mathrm{p}=1.00)$.

\section{Discussion}

The data obtained in this study demonstrates a $29.23 \%$ prevalence of stress UI in obese and morbidly obese women undergoing preparation for bariatric surgery. Additionally, there was a positive association between age and incontinence impact on women's QOL.

The study's initial hypothesis was only partially confirmed: the prevalence of UI in women was lower than expected for their age, considering that, as shown by Gerten et al. [21], the prevalence of UI in this population ranges from 46 to $67 \%$. Moreover, according to Castro et al. [22], the prevalence of UI in women undergoing the preoperative period for bariatric surgery can reach $70.8 \%$. In the same vein, the literature highlights the increase of UI prevalence in morbidly obese women when compared to obese women [23]. In addition to high UI prevalence, we also hypothesized a positive association between BMI and UI, which also remains unconfirmed.

According to Alling Møller et al. [24], excess weight may increase abdominal pressure, building bladder pressure and leading to greater mobility of the urethra and bladder neck, which may then lead to UI. That said, certain factors may have contributed to the lower prevalence of UI and the lack of association or correlation between BMI and UI seen in this study. Firstly, the sample size was small $(\mathrm{n}=19)$, while BMI values were homogeneous, with low standard deviation $\left(46.73 \pm 8.33 \mathrm{~kg} / \mathrm{m}^{2}\right)$. Without enough BMI variation, it is no surprise that no association between BMI and UI prevalence could be found, as most of the participants presented BMI class II or III. Although these factors could be seen merely as study limitations, such lack of variation may also be explained by the fact that all respondents were waiting for bariatric surgery, premised on similar anthropometric characteristics among patients, according to the procedure's clinical criteria. Secondly, another likely factor of low UI prevalence might have been participants' inhibition or embarrassment in discussing the subject of urinary incontinence. It is worth mentioning the results of a systematic review by Volkmer et al. [25], in which the majority of women chose to face urinary incontinence "silently." This shows how important it is for health professionals to better understand the personal, familial, and social implications of female UI. Lastly, another possible factor of low UI prevalence in this study are the motivational traits of the volunteers: interviews were performed in a medical clinic specializing in bariatric surgery, and their surgeries were to take place at a nearby date; in this context, women's main complaints did not concern urinary incontinence directly, but rather focused on their excess weight. 
This study shows that health professionals, including physicians, physiotherapists and nurses, should be aware of the symptoms associated with lower urinary tract dysfunctions in women with obesity—regardless of prevalence.

Even with a prevalence of UI lower than expected among morbidly obese women, excess weight and obesity are still regarded as potentially modifiable UI risk factors. Since weight reduction is a treatment for UI [26], this study's participants may have benefited from an objectively decreased UI prevalence.

This study also aimed to evaluate quality of life in obese women suffering from UI and, despite the fact that the literature reports severe lifestyle impacts of UI-with repercussions over social, professional, sexual, and family life $[8,9,21]$-our results purport the opposite. Once again, this discrepancy is likely explained by our sample of an homogeneous population in regards to personal motivations and pre-surgical expectations, with hardly any complaints about UI.

Although the questionnaire employed here is an important tool for the evaluation of women's UI in clinical research [19], while the self-administered application process is considered optimal due to avoiding examiner interference, participants' answers were naturally tinted by subjectivity, perhaps due to shame or embarrassment. As an alternative, urodynamic assessment could contribute to an objective, reliable UI diagnosis, avoiding any cause for embarrassment. According to Feldner Jr et al. [17], a complete UI diagnosis consists of clinical history, surgical history, quality of life questionnaire, physical examination, voiding diary, pad test, and urodynamic assessment. Thus, urodynamic study would be an important step after the KHQ questionnaire, so as to confirm participants' self-reported complaints or lack thereof.

Despite the hypothesis that obese women have greater UI severity, Oliveira et al. [27] used the KHQ to measure and compare the effects of BMI and UI and showed that the KHQ was unable to accurately ascertain, in any of its domains, a relationship between QOL deterioration and BMI increase in women. Conversely, in a validation analysis, KHQ domains were proven to positively correlate, with the instrument accurately measuring the impact of UI on participants' QOL [28].

Based on KHQ responses obtained from morbidly obese participants, as well as scores for each domain, we observed that the impacts of UI became greater with increasing age-even though most participants reported that UI had little effect over their lives. Thus, advanced age did in fact contribute to the decline of QOL in obese women. Meanwhile, the lowest-scoring domains, in decreasing order, were the following: "general health perception," "emotions," "roles limitations," "sleep and energy," "physical limitations," "social limitations," "personal limitations."

These data are very similar to those reported by Mourão et al. [29], who interviewed women over 40 years old who were participating in a physical activity group, noting that the "incontinence impact" domain had a higher mean value in comparison to the other domains. The other domains ranked as follows (in decreasing order): "general health perception," "emotions," "roles limitations," "sleep and energy," "physical limitations," "relationships," "social limitations."

Lopes et al. [30] interviewed 164 women with UI symptoms aged 25 to 85 years, and, in agreement with our results, observed that the "incontinence impact" domain was predominant in the older population. The authors also stated that their domain-specific analysis showed great result variability, which they explained by participants' underestimation of symptoms linked to embarrassment in dealing with the subject, as suggested in this study.

Dedicação et al. [31] found that UI's impact on QOL varied considerably among women. Standard deviation in their results remained high in the different KHQ domains, pointing to the subjective nature of the questionnaire, likely related to the social, cultural and religious diversity underlying the studied population.

It should be noted that this study highlights the added importance of health care for women who suffer from UI associated with obesity, since this combination may compromise QOL to a greater degree.

Among the limitations of this study, worthy of mention is the lack of urodynamic assessments in order to confirm UI and later associate it with participants' symptomatology. On the other hand, self-reported UI diagnosis is a simple method, which can be applied to a large population at no additional cost. Another limitation may be the study's timing, a period very close to participants' scheduled bariatric surgery. Respondents had high expectations regarding the procedure's results, having waited in line for a 
considerable amount of time; this may have led to an underestimation of incontinence complaints.

This study emphasizes that health professionalsincluding physicians, physiotherapists, and nursesshould be acutely aware of symptoms associated with lower urinary tract dysfunction in women with obesity.

\section{Conclusion}

The prevalence of UI symptoms reported by women with morbid obesity was $29.23 \%$, lower than literature reports. UI impacts women's QOL, especially in terms of general health perception, social, professional, family and sexual relationships. UI becomes more significant with increasing age. These results may contribute to guiding the practice of health care for women with obesity, with an emphasis on urinary dysfunctions and improvement of QOL, especially during the aging process.

\section{References}

1. Abrams P, Andersson KE, Birder L, Brubaker L, Cardozo L, Chapple C, et al. 4th International Consultation Recommendations of the International Scientific Committee: the major evaluation and treatment of urinary incontinence, pelvic organ prolapse and faecal incontinence. Eval treat urin incontinence, pelvic organ prolapse faecal incontinence. 2009;1767-820.

2. Sensoy N, Dogan N, Ozek B, Karaaslan L. Urinary incontinence in women: prevalence rates, risk factors and impact on quality of life. Pak J Med Sci. 2013;29(3):818-22.

3. Fuganti PE, Gowdy JM, Santiago NC. Obesity and smoking: are they modulators of cough intravesical peak pressure in stress urinary incontinence? Int Braz J Urol. 2011;37(4):528-33.

4. Fonseca ESM, Camargo ALM, Castro RA, Sartori MGF, Fonseca MCM, Lima GR, et al. Validação do questionário de qualidade de vida (King's Health Questionnaire) em mulheres brasileiras com incontinência urinária. Rev Bras Ginecol e Obs. 2005;27(5):235-42.
5. Kuruba R, Almahmeed T, Martinez F, Torrella TA, Haines K, Nelson LG, et al. Bariatric surgery improves urinary incontinence in morbidly obese individuals. Surg Obes Relat Dis. 2007;3(6):586-90.

6. Subak LL, Richter HE, Hunskaar S. Obesity and urinary incontinence: epidemiology and clinical research update. J Urol. 2009;182(6 Suppl):S2-7.

7. Ballard AC, Richter HE. The impact of obesity and weight loss on urinary and bowel incontinence symptoms in women. Menopausal Med. 2011;19(3):S1-7.

8. Richter HE, Kenton K, Huang L, Nygaard I, Kraus $S$, Whitcomb E, et al. The impact of obesity on urinary incontinence symptoms, severity, urodynamic characteristics and quality of life. J Urol. 2010;183(2):622-8.

9. Ternent L, Vale L, Buckley B, Glazener C. Measuring outcomes of importance to women with stress urinary incontinence. BJOG. 2009;116(5):719-25.

10. Alappattu M, Neville C, Beneciuk J, Bishop M. Urinary incontinence symptoms and impact on quality of life in patients seeking outpatient physical therapy services. Physiother Theory Pract. 2016;32(2):107-12.

11. Aguilar-Navarro S, Navarrete-Reyes AP, GradosChavarria BH, Garcia-Lara JM, Amieva H, Avila-Funes JA. The severity of urinary incontinence decreases health-related quality of life among communitydwelling elderly. J Gerontol A Biol Sci Med Sci. 2012;67(11):1266-71.

12. Schwartz B, Wyman JF, Thomas W, Schwarzenberg SJ. Urinary incontinence in obese adolescent girls. J Pediatr Urol. 2009;5(6):445-50.

13. Brown JS, Seeley DG, Fong J, Black DM, Ensrud KE, Grady D. Urinary incontinence in older women: who is at risk? Study of Osteoporotic Fractures Research Group. Obstet Gynecol. 1996;87(5 Pt 1):715-21.

14. Bulbuller N, Habibi M, Yuksel M, Ozener O, Oruc MT, Oner OZ, et al. Effects of bariatric surgery on urinary incontinence. Ther Clin Risk Manag. 2017;13:95-100. 
15. Qaseem A, Dallas P, Forciea MA, Starkey M, Denberg TD, Shekelle P, et al. Nonsurgical management of urinary incontinence in women: a clinical practice guideline from the American College of Physicians. Ann Intern Med. 2014;161(6):429-40.

16. Pereira VS, Escobar AC, Driusso P. Effects of physical therapy in older women with urinary incontinence: a systematic review. Rev Bras Fisioter. 2012;16(6):463-8.

17. Feldner Jr PC, Sartori MGF, Lima GR, Baracat EC, Girão MJBC. Diagnóstico clínico e subsidiário da incontinência urinária. Rev Bras Ginecol Obs. 2006;28(1):54-62.

18. Simeonova Z, Milsom I, Kullendorff AM, Molander U, Bengtsson $\mathrm{C}$. The prevalence of urinary incontinence and its influence on the quality of life in women from an urban Swedish population. Acta Obstet Gynecol Scand. 1999;78(6):546-51.

19. Tamanini JTN, D’Ancona CAL, Botega NJ, Netto Jr NR. Validação do "King's Health Questionnaire" para o português em mulheres com incontinência urinária. Rev Saude Publica. 2003;37(2):203-11.

20. Kelleher CJ, Cardozo LD, Khullar V, Salvatore S. A new questionnaire to assess the quality of life of urinary incontinent women. Br J Obstet Gynaecol. 1997;104(12):1374-9.

21. Gerten KA, Richter HE, Burgio KL, Wheeler TL, Goode PS, Redden DT. Impact of urinary incontinence in morbidly obese women versus women seeking urogynecologic care. Urology. 2007;70(6):1082-5.

22. Castro LA de, Sobottka W, Baretta G, Freitas ACT. Efeitos da cirurgia bariátrica na função do assoalho pélvico. ABCD Arq Bras Cir Dig. 2012;25(4):263-8.

23. Whitcomb EL, Lukacz ES, Lawrence JM, Nager CW, Luber KM. Prevalence and degree of bother from pelvic floor disorders in obese women. Int Urogynecol J Pelvic Floor Dysfunct. 2009;20(3):289-94.

24. Alling Møller L, Lose G, Jørgensen T. Risk factors for lower urinary tract symptoms in women 40 to 60 years of age. Obstet Gynecol. 2000;96(3):446-51.
25. Volkmer C, Monticelli M, Reibnitz KS, Brüggemann OM, Sperandio FF. Incontinência urinária feminina: revisão sistemática de estudos qualitativos. Cien Saude Colet. 2012;17(10):2703-15.

26. Hunskaar S. A systematic review of overweight and obesity as risk factors and targets for clinical intervention for urinary incontinence in women. Neurourol Urodyn. 2008;27(8):749-57.

27. Oliveira E, Lozinsky AC, Palos CC, Ribeiro DDM, Souza AMB, Barbosa CP. Influência do índice de massa corporal na incontinência urinária feminina. Rev Bras Ginecol Obs. 2010;32(9):454-8.

28. Badia Llach X, Castro Díaz D, Conejero Sugrañes J. [Validity of the King's Health questionnaire in the assessment of quality of life of patients with urinary incontinence. The King's Group]. Med Clin (Barc). 2000;114(17):647-52.

29. Mourão FAG, Lopes LN, Vasconcellos NPC, Almeida MBA. Prevalência de queixas urinárias e o impacto destas na qualidade de vida de mulheres integrantes de grupos de atividade física. ACTA FISIATR. 2008;15(3):170-5.

30. Lopes MHB de M, Higa R. Restrições causadas pela incontinência urinária à vida da mulher. Rev Esc Enferm USP. 2006;40(1):34-41.

31. Dedicação AC, Haddad M, Saldanha MES, Driusso P. Comparação da qualidade de vida nos diferentes tipos de incontinência urinária feminina. Brazilian J Phys Ther. 2009;13(2):116-22. 